\title{
The Relationship between Principal Supervision and Interpersonal Communication with the Work Ethic of Teachers
}

\author{
Desrina \\ SMA Negeri 1 Prabumulih \\ e-mail: desriana437@gmail.com \\ Happy Fitria \\ Universitas PGRI Palembang \\ e-mail: happyfitriamufly@univpgri-palembang.ac.id \\ Mulyadi \\ Universitas PGRI Palembang \\ e-mail:mulyadi@univpgri-palembang.ac.id \\ Article History: Received on 30 September 2020, Revised on 10 October 2020, \\ Published on 11 October 2020
}

\begin{abstract}
This study aimed at analyzing the relationship between principal supervision and interpersonal communication partially and simultaneously with the work ethic of teachers at Prabumulih Public High School. This research was a survey research with a quantitative approach. The research subject was the teacher while the object of the research was the supervision of the principal and the interpersonal communication. The results obtained indicate that there is a relationship between the principal's supervision and interpersonal communication partially and simultaneously significant with the work ethic of teachers in SMA Negeri Prabumulih.
\end{abstract}

Keywords: Principal's Supervision, Interpersonal Communication, Work Ethic of Teachers

\section{A. Introduction}

The National Education System is an integrated educational component to achieve the goals of national education. Education is an effort so that humans can develop their potential through the learning process or other methods that are known and recognized by society. The values that exist in this society are the result of education, because that is why education is a very influential part of society to hone their skills and knowledge.

Education is a conscious effort to build quality human resources to compete (Tobari et.al., 2018). According to Ekosusilo (2003) that education is a matter that must be prioritized for the prosperity of a nation, this as a main activity in cultivating human resources is proven to have a major impact on improving the economy, so that the benefits in education investment are better than physical investment.

Various knowledge of skills, values and attitudes needed by students are obtained through the educational process, so that the knowledge gained can be used to work productively. Adequate human resources are needed in this era of globalization. The direction of national education development is prioritized as stated in the 1945 Constitution. Formal educational 
institutions such as schools are the organizers of teaching and learning activities in order to achieve these educational goals.

Clause 5 Paragraph 1 in the Regulation of the Minister of State Apparatus Empowerment and Reform Number 16 of 2009 has been regulated on Teacher Functional Position and Credit Score, which explains that the main task of the Teacher is to educate, teach, guide, direct, train, assess, and evaluate students at Early childhood education through formal education, basic education, and secondary education as well as additional tasks that are relevant to school functions. Then article 6 states the teacher's obligations in carrying out the task are carry out learning planning, implementing quality learning, assessing and evaluating learning outcomes, as well as learning improvement and enrichment; academic qualifications and competencies on an ongoing basis in line with developments in science, technology, and arts; must be improved and developed; consideration of gender, religion, ethnicity, race, and certain physical conditions, family background, and socioeconomic status of students in learning must be objective and not discriminatory against; laws and regulations, laws, and Teacher's code of ethics, as well as religious and ethical values must be upheld; and the unity and integrity of the nation must be preserved and nurtured.

The principal is the leader as organizer and manager of activities so that they become focused, focused and experience significant improvement. Fauzan (2010) states that the factors that are influenced by teacher performance are improving teacher education, teaching supervision, upgrading programs, a conducive climate, facilities and infrastructure, physical and mental conditions of teachers, principal leadership, guaranteed teacher welfare, and managerial abilities of principals also increased. Explaining According to Mulyasa (2007), supervision is a process that is specially made to help teachers and supervisors carry out various kinds of daily tasks at school.

According to Engkoswara and Komariah (2010) there are several supervisory functions, namely 1) research function, 2) assessment function, 3) improvement function, and 4) development function. A teacher as the main source of a learning process can carry out his duties maximally through three ways: First, it focuses on students, namely that teaching and learning activities focus on the needs of students, namely the extent to which students feel educated, inspired, guided and motivated or called student centered teaching. Second, there is continuous improvement in the teaching and learning process. Quality results can only be produced by a series of serious steps on the part of the school, especially the principal as a supervisor to the teachers for whom he is responsible. Supervision activities require continuous improvement towards perfection in accordance with the best didactic and pedagogical principles aimed at the needs of students. The third is total involvement in the quality improvement system, thus the movement and efforts to improve the quality of schools become a continuous need and culture, so one important factor to achieve work ethic, which is carried out by the principal is to carry out academic supervision. Because the success or failure of education is inseparable from the role of the principal as a supervisor who tries to find educational problems and always fixes the weaknesses that occur in a teacher.

Supervision activities are things that must be considered because with this activity it will be seen between the principal and the teacher that interpersonal communication occurs. Communication or exchange of information with certain meanings and meanings occurs because of the academic supervision process. The meaning of communication can be interpreted as the process of delivering information and ideas. According to Hardjana (2003) 
face-to-face interaction between two or several people is known as interpersonal communication, where there is direct delivery of messages and those who receive messages can receive and respond directly as well. Then there is mutual influence between the sender and recipient of the message due to the interaction.

According to Rakhmat (2005) that the interpersonal communication process must understand the impact of a symbiotic relationship between communication and relational development, relational development is greatly influenced by communication and in turn the characteristics of communication between the parties involved in this relationship will be influenced by relationship development or simultaneously influence each other.

Teacher work will increase if teachers get good guidance and have a strong work ethic. Soehito (1978) explains that ethos is a philosophical term which means a character that must become one's character in playing its role in certain activities. Magnis (1978) explains that ethos means attitude, the will that is required of certain activities; work ethic is the basic attitude of a person or group of people in doing their job. Yousef (2000) explains that employees who have a high work ethic are reflected in their behavior such as like working hard, being fair, not wasting time during working hours, the desire to give more than just being hinted at, willing to cooperate, respect for co-workers and so on.

Based on this opinion the principal and interpersonal communication owned by the teacher and various other elements in education have a relationship with the work ethic of the teacher in a learning process. Work ethic and coaching play an important role in improving teacher performance in order to maximize learning outcomes in the hope of achieving predetermined goals.

Based on the results of observations and observations of researchers at SMA Negeri in Prabumulih on October 26, 2019, researchers found indicators that stated that academic supervision or teacher coaching had not been carried out routinely by the principal, including administrative management in teaching such as lesson plans, annual programs, semester programs were not carried out routine, supervision activities are carried out if there is an order from the center only. Supervision that should be carried out regularly to see an increase in the work ethic of teachers both in teaching preparation and in teaching in the classroom. Then from the results of observations made that the work ethic of teachers at SMA Negeri in Prabumulih was not optimal, after conducting interviews with several teachers, there were results that stated their work ethic was still low, because various things including supervision activities that were not carried out routinely made some teachers not carry out their duties maximally and interpersonal communication between teachers and various elements in schools has not been well established.

In addition to interviews with several teachers, researchers also found that there was a relationship or communication that was not good between teachers and teachers so that this affected the work ethic of teachers in schools both in learning activities and outside of learning. Because, these two factors greatly affect the work ethic of the teaching and learning process, namely supervision and interpersonal communication activities between various elements of education in which it is not supportive, teachers at SMA Negeri in Prabumulih have a work ethic that is not yet optimal. This can affect the quality of education, the quality or work ethic of a teacher cannot be implemented optimally so that it affects the quality of education at Prabumulih State Senior High School which should be improved. 


\section{B. Methods}

This research is a survey research with a quantitative approach. The research subject was the teacher while the object of the research was the supervision of the principal and the interpersonal communication of SMA Negeri Prabumulih.

The population in this study were all 100 teachers and principals at SMA Negeri Prabumulih. The sample in the study was taken teachers who already had teaching experience over 5 years and had an undergraduate education. To get the subjectivity of the teacher's assessment of the supervision of the principal and interpersonal communication. In this study using purposive sampling. Sugiyono (2017) explains that purposive sampling is a non-random sampling technique in which the researcher determines sampling by determining specific characteristics that are in accordance with the research objectives so that it is expected to be able to answer research problems. The sample used in this study is only three schools, namely SMA Negeri 1, Prabumulih SMAN 4 Prabumulih and SMAN 6 Prabumulih because the researcher wants to take one school that represents the sub-districts in Prabumulih. Where SMA Negeri 1 Prabumulih represents Prabumulih Utara sub-district which is in the city center with a dense population, SMAN 4 Prabumulih represents Rambang Kapak Tengah sub-district which is in the western part of Prabumulih City in the rural area and SMAN 6 Prabumulih represents Cambai sub-district in the eastern part of Prabumulih City. In addition, the schedule of supervision activities carried out at the high school has the same schedule.

This study used a questionnaire to collect data. Before the questionnaire is distributed, the validity and reliability of the questionnaire are tested first. The data analysis technique in this study used the Product Moment correlation data analysis technique with the help of the SPSS for Windows Version 22 program. The stages of the analysis included: (1) descriptive analysis, (2) analysis requirements test (normality test, linearity test and homogeneity test), and (3) hypothesis testing.

\section{Results and Discussion}

Table 1. Results of Simple Correlation Statistical Analysis Correlations

\begin{tabular}{|ll|l|l|}
\hline & & $\begin{array}{l}\text { Supervision of the } \\
\text { Principal }\end{array}$ & Teacher Work Ethic \\
\hline Supervision of the Principal & Pearson Correlation & 1 & 637 \\
& Sig. (2-tailed) & & 000 \\
& $\mathrm{~N}$ & 96 & 96 \\
\hline Teacher Work Ethic & Pearson Correlation & 637 & 1 \\
& Sig. (2-tailed) &, 000 & \\
& $\mathrm{~N}$ & 96 & 96 \\
\hline
\end{tabular}

Table 2. Results of Simple Correlation Statistical Analysis

\begin{tabular}{|c|c|c|c|}
\hline & & Teacher Work Ethic & $\begin{array}{l}\text { Interpersonal } \\
\text { Communication }\end{array}$ \\
\hline Teacher Work Ethic & $\begin{array}{l}\text { Pearson Correlation } \\
\text { Sig. (2-tailed) } \\
\mathrm{N}\end{array}$ & 96 & $\begin{array}{l}497^{* *} \\
.000 \\
96\end{array}$ \\
\hline Interpersonal Communication & $\begin{array}{l}\text { Pearson Correlation } \\
\text { Sig. (2-tailed) } \\
\mathrm{N}\end{array}$ & $\begin{array}{l}497^{* *} \\
000 \\
96\end{array}$ & 96 \\
\hline
\end{tabular}


Table 3. The results of the multiple regression analysis $\mathrm{X} 1$ and $\mathrm{X} 2$ on $\mathrm{Y}$

\begin{tabular}{|c|c|c|c|c|c|}
\hline Model & Sum of Squares & Df & Mean Square & $F$ & Sig. \\
\hline $\begin{array}{l}\text { Regression } \\
\text { Residual } \\
\text { Total }\end{array}$ & \begin{tabular}{|l|}
570,778 \\
1420,180 \\
1990,958
\end{tabular} & $\begin{array}{l}2 \\
94 \\
96\end{array}$ & $\begin{array}{l}285,389 \\
15,271\end{array}$ & 18,689 &, $000^{b}$ \\
\hline
\end{tabular}

Based on the correlation test, it is known that the significant value is $0.000<0.05$. Then it is known that the correlation coefficient value is 0.637 . Thus it can be stated that there is a relationship between the supervision of the principal and the work ethic of the teachers at Prabumulih High School, with the level of the correlation coefficient in the positive category while the relationship is strong.

Then it is known that the correlation coefficient value is 0.497 . Thus it can be stated that there is a relationship between interpersonal communications with the work ethic of teachers at Prabumulih Senior High School, with the level of the correlation coefficient in the positive category while the relationship is with the medium category.

To test the relationship together, obtained $\mathrm{F}$ count of 18.689 with a significance level of 0.000 $<$ probability value $\alpha 0.05$ while $\mathrm{F}$ table corresponds to a significance level of 0.05 (2.94) of 3.94 so that $\mathrm{F}$ count $>\mathrm{F}$ table $(18.689>3.09)$ so that Ho3 is rejected, meaning that there is a significant relationship jointly between the supervision of the principal and interpersonal communication with the work ethic of teachers at Prabumulih High School.

The results of the research and discussion in this study were supported by several previous studies, including research conducted by Maria (2014) who found that there was a significant and positive relationship between interpersonal communication and the work ethic of teachers at Public Elementary Schools in Delta Pawan District, Ketapang Regency. . Then Selvia (2015) conducted research on the Effect of Principal Academic Supervision and the Work Environment on the Performance of High School Economics Teachers (SMA) in Sleman Regency. Then the research conducted by Happy (2012) The Effect of Principal Supervision and Teacher Work Motivation on the Performance of Economics/Accounting Teachers in SMA/MA/SMK in Pekalongan City.

Furthermore, research conducted by Farhan (2018) entitled The Effect of Principal Academic Supervision on the Performance of Islamic Religious Education Teachers (PAI) at SMP Negeri 7 Bandar Lampung. This research is motivated by the success that the principal of SMP Negeri 7 Bandar Lampung has in carrying out academic supervision of the principal, especially on the performance of Islamic Religious Education (PAI) teachers, in this regard researchers are interested in conducting research on the Effect of Principal's Academic Supervision on Performance Islamic Religious Education Teacher (PAI) at SMP Negeri 7 Bandar Lampung.

Furthermore, research conducted by Purwanto (2014) The Effect of Principal Supervision, Principal Management Openness, and Teacher Work Motivation on Teacher Performance (Case Study of Assisted Teachers and Non-Permanent Teachers at Pracimantoro State Junior High School, Wonogiri). Next, research conducted by Nanang (2012) on the relationship between principal interpersonal communication and teacher work ethic with teacher job 
Volume 1 (2) 2020

E-ISSN: 2723-6919 P-ISSN:2746-0827

satisfaction at private SMP Sabilina Tembung, Percut Sei Tuan District, with the result that there is a significant relationship between teacher work ethic and teacher job satisfaction has a correlation coefficient of 0.445 .

Iswandi (2017) Relationship between Academic Supervision and Interpersonal Communication with the Work Ethic of Teachers in Public Elementary Schools. The results of the partial correlation analysis found that: (1) there is a positive and significant correlation between academic supervision (X1) and the work ethic of the teacher (Y) of ( $\mathrm{r} \mathrm{X} 1 \mathrm{Y}=0.427)$. (2) there is a positive and significant correlation between interpersonal communication (X2) and the work ethic of the teacher $(\mathrm{Y})$ of $(\mathrm{r} \mathrm{X} 2 \mathrm{Y})=0.432)$, (3) there is a positive and significant correlation between $(\mathrm{X} 1)$ and $(\mathrm{X} 2)$ together with $(\mathrm{Y})$ of $(\mathrm{rX} 1 \mathrm{X} 2 \mathrm{Y}=0.475)$, (4) Contribution (X1) to (Y) of $18.23 \%$, the remaining $81.77 \%$ is influenced by other variables, (5) Contribution (X2) to (Y) amounting to $18.66 \%$, the remaining $81.34 \%$ is influenced by other variables not examined in this study.

\section{Conclusion}

Based on the results of data analysis, it can be concluded that there is a relationship between the supervision of the principal and the work ethic of teachers in SMA Negeri Prabumulih; there is a relationship between interpersonal communication and the work ethic of teachers in SMA Negeri Prabumulih; there is a relationship between principal supervision and interpersonal communication with the work ethic of teachers in SMA Negeri Prabumulih.

\section{E. Acknowledgement}

We thank to the principal of SMA Negeri 1 Prabumulih, Rector Universitas PGRI Palembang who gave us the support to do this wonderful project. This project was funded independent. We would also like to thank our friends in Educational Management who helped us a lot in finalizing this project within the limited time frame.

\section{References}

Ekosusilo, M. (2003). Sekolah Unggul Berbasis Nilai [Value-Based Excellence School]. Sukoharjo: Univet Bantara Press.

Engkoswara., \& Komariah. (2010). Administrasi Pendidikan [Education administration]. Bandung: Alfabeta.

Hardjana. (2003). Komunikasi intrapersonal \& Komunikasi Interpersonal [Intrapersonal Communication \& Interpersonal Communication]. Yogyakarta: Penerbit Kanisius.

Iswandi. (2017). Hubungan Supervisi Akademik Dan Komunikasi Interpersonal Dengan Etos Kerja Guru pada Sekolah Dasar Negeri [Relationship between Academic Supervision and Interpersonal Communication with the Work Ethic of Teachers in Public Elementary Schools]. Tesis. Program Magister AP, FKIP Universitas Tanjungpura Pontianak.

Magnis. (1978). Etos Kerja Sektor Informal Pedagang Kaki Lima [Work Ethic of the Informal Sector of Street Vendors]. Penelitian Individual. Surabaya: Unbraw. 
Journal of Social Work and Science Education

Volume 1 (2) 2020

E-ISSN: 2723-6919 P-ISSN:2746-0827

Maria. (2014). Hubungan Supervisi Akademik dan Komunikasi Interpersonal dengan Etos Kerja Guru pada Sekolah Dasar Negeri [The Relationship of Academic Supervision and Interpersonal Communication with the Work Ethic of Teachers in Public Elementary Schools]. Jurnal Modernisasi Pendidikan Fakultas Keguruan Universitas Kanjuruhan Malang.

Mulyasa. (2007). Standar Kompetensi dan Sertifikasi Guru [Competency Standards and Teacher Certification]. Bandung: PT Remaja Rosdakarya.

Nanang. (2012). Hubungan Komunikasi Interpersonal Kepala Sekolah Dan Etos Kerja Guru Dengan Kepuasan Kerja Guru Di SMP Swasta Sabilina Tembung Kecamatan Percut Sei Tuan [Relationship between Principal Interpersonal Communication and Teacher Work Ethic with Teacher Job Satisfaction at Sabilina Tembung Private Middle School, Percut Sei Tuan District]. Tesis. Jember: PPs Universitas Jember.

Pasal 5 Ayat 1 Peraturan Menteri Pendayagunaan Aparatur Negara dan Reformasi Nomor 16 Tahun 2009 tentang Jabatan Fungsional Guru dan Angka Kreditnya [Clause 5 Paragraph 1 Regulation of the Minister of Administrative Reform and State Apparatus Number 16 of 2009 concerning Teacher Functional Position and Credit Score].

Rakhmat, J. (2005). Psikologi Komunikasi [Psychology of Communication]. Bandung : Remaja Rosdakarya.

Selvia. (2015). Pengaruh Supervisi Akademik Kepala Sekolah Dan Lingkungan Kerja terhadap Kinerja Guru Ekonomi Sekolah Menengah Atas (SMA) di Kabupaten Sleman [Pengaruh Supervisi Akademik Kepala Sekolah Dan Lingkungan Kerja terhadap Kinerja Guru Ekonomi Sekolah Menengah Atas (SMA) di Kabupaten Sleman]. Tesis. Yogyakarta: FISE UNY.

Soehito. (1978). Ilmu, teori dan filsafat komunikasi [Science, theory and philosophy of communication]. Bandung : Citra Aditya Bakti

Sugiyono. (2017). Metode Penelitian Kuantitatif, Kualitatif, dan $R$ \& $D$ [Quantitative Research Methods, Qualitative, and $R \& D$ ]. Bandung: Alfabeta.

Tobari., Kristiawan, M. \& Asvio N. (2018). The strategy of Headmaster on Upgrading Educational Quality in Asean Economic Community (AEC) Era. International Journal of Scientific \& Technology Research 7 (4).

Yousef, M. K. (2000). Thermoneutral Zone. In: M.K. Yousef (Ed.). Stress physiology of livestock. Vol. II. CRC Press, Inc. Boca Raton, Florida. 68-69. 